\title{
Tax System and Its Development in Kosovo
}

\author{
Ramadan Kryeziu \\ Ph.D. Candidate "Josipa Jurja Strossmayera" University of Osijek, Faculty of Economics in Osjek \\ Email: ramadan_kryeziu@hotmail.com \\ Sakip Imeri \\ Ph.D. Candidate "Josipa Jurja Strossmayera" University of Osijek, Faculty of Economics in Osjek \\ Email: sakipimeri@gmail.com
}

\section{Doi:10.5901/ajis.2016.v5n3s1p382}

\begin{abstract}
With this work we intend to track successive chronological steps of tax system development in Kosovo in the post war period, first under the international protectorate and then, after 2008 as an independent state. The most important changes that accompanied Tax System in Kosovo is when it evaluated from UNMIK system of regulations. While the emphasis will remain on treatment of current important change of tax system, revealing a challenge on most discussed issue of 2001, the year when for the first time is implemented the VAT, then in 2002, when it is implemented Wage Tax, and Profit Tax for legal persons, which by that time were taxed with Presumptive Tax, then in 2005 it was done a tax reform, replacing Presumptive Tax, Wage Tax and Profit Tax with two types of taxes, as: Personal Income Tax, which taxes physical persons and Corporate Income Tax, which taxes legal persons.
\end{abstract}

Keywords: tax system, value added tax, profit tax, personal income.

\section{Introduction}

Taxes are a topic that always brings interest and debate in society in general but also in taxpayer's family. Knowing that there is a lot of interest and debates I have put to myself, to accompany this event of development of Kosovo Tax System, a paper work, however small but very substantial for the society and taxpayers' families.

After the war, the Kosovo Tax Policy System was fragile, uncompleted and unimplemented. The self-governing institutions of that time were not powerful to decide on good tax policies. First years of post war Kosovo has faced with a disaccorded and rushing tax intervention based mainly on experiences of other countries and not in line with real situation and needs of postwar Kosovo, which in many sectors it was required to start from scratch. From 1999 to 2003, UNMIK was the creator of tax and policy system in Kosovo, almost everything was copied from other countries, both from countries in transition and EU countries.

Tax Administration of Kosovo was established on 17 January 2000 under the direction and administration of UNIMK, and from February 2003 the powers of leadership were transferred to Ministry of Economy and Finance, but even then there was no possibility to make reforms. From January 2005 the tax policy starts with first tax changes or with implementation of new taxes, as Corporate Income Tax (CIT) and Personal Income Tax (PIT) and this situation has continued until the end of 2008 or beginning of 2009. At the beginning of 2009 it has started the implementation of new law in Kosovo with reduction of tax rates, also, were reduced tax rates on interest, rent, game of chance, capital gains, sale of intangible property, etc. from $20 \%$ to $10 \%$. Whereas, VAT undergoes through an increase from $15 \%$ to $16 \%$, which in reality caused a light increase on prices. And from the middle of year 2012 there have been an increase of rate from $5 \%$ to $9 \%$ for businesses dealing with services, professional activities, artisan, entertainment and similar. They pay on quarterly basis but not less than 37.5 euros and they do not pay on real basis.

In our country tax system consists of package of laws, regulations, instruction, agreements with other countries where are reflected the type of fees and taxes applicable in Kosovo, their rates, procedures to levy and remove taxes, procedures for assessment, collection and audit.

Tax - is any tax, contribution or other amount paid to TAK under the applicable legislation in Kosovo. Therefore tax and fee is called any liable payment under law, made in the favor of state budget, by physical and legal persons of a country, based on income or property they possess, consumption of goods and services they receive. They make the 
main source of revenues for the state budget (over 90\%). In many cases the term "tax" and "fee" are used with the similar meaning, although taxes are paid based on income or profits and goods consumed, and fees are paid for various services that state authorities provide to their citizens.

Taxes and fees must respond to these principles:

Legal principle, under which rules, values and ways to collects taxes and fees of all kinds, must be focused through the law, meaning to be voted in the parliament.

Equality principle, under which the common contribution must also be distributed among citizens based on their capabilities and their categorization.

To be trustful and respected, and to be comparable with leading administrations in Europe.

Keeping the TAK values that are:

Professionalism

Integrity and Honesty

Efficiency and Effectiveness

Service Excellence

Transparency.

Taxes are divided in two big groups; direct and indirect.

Direct taxes include those taxes calculated on income, profits, immovable property and public services of certain physical and legal persons and it should be remitted to state budget by them. On direct taxes are included: tax on income, tax on profit, tax on property, etc.

Indirect taxes are called those that are included on price level of different products, goods and services and are paid as a part of these prices by consumers and are remitted in the state budget by the sellers of products, goods and services. On indirect taxes and fees are included: value added tax, customs duties, excise, etc.

Proportionality and progressivity are two way of calculation for the value of taxes and fees. Currently they make the debate on the aim and fairness of fiscal system. A promotional tax is applied with same tax coefficients against the tax base (for example, profit tax). Tax base is the economic value (of income, property), which is used as basis for tax calculation. The supporters or partisans of proportionality consider that this is fair calculation, because everyone contributes on same proportion with its income. They also think that this way favor the fiscal neutrality (limited deformations from the economic election of agents, lack of threshold effect, in particular). In general, proportional taxes are more simple to be charged and as such less costing to be collected.

In Kosovo we do not apply this category, progressive tax, as neighbor countries do so. Progressive tax discourages supplementary work and investments.

\section{Changes of Chronological Flow on Tax System of Kosovo}

Kosovo is a postwar country and with an economy not at all stabile has various changes, both political and on the area of economy in taxes.

On the first years when it was established central fiscal authority within the Ministry of Finance, taxes were governed by regulations and based on these regulations were imposed and collected taxes. Therefore, the tax assessment and collection was covering only one category of taxable persons generating income and only on hotels and services, then on the following years there was Presumptive Tax divided on areas where the activity was exercised. Tax system in Kosovo, has evolved from the UNMIK regulation system to tax law system promulgated by the Assembly of Republic of Kosovo, which are in line with international standards and are materializing the EU principles.

The biggest evolvement is VAT, which has started to be implemented for the first time in 2001. This tax type, is understandable that has caused a lot of debate, always in light of rejection by the taxpayers' partisans that did not understood that this tax type is indirect and it does not reduce their profit, but taxpayers have the role of intermediator to collect this tax from consumers.

It is understandable that as new country under the supervision of protectorate always there were improvements and reforms in the Kosovo tax system. Improvements of tax system, its perfection with modern methods on administration and collection of taxes and fees it was main goal on enhancement of budget revenues.

In this frame a special importance had drafting and approval of basic tax principles, which were promulgated by Kosovo Assembly, which placed the basic principles of tax system under the definition that "tax is an obligation of people to face the state general expanses".

No tax, of any kind, cannot be charged and collected other than by law, finally by removing tribute tax or any 
imposition as tax. The tax system implemented by Kosovo during these years, in core, kept and improved a part of fiscal system borrowed from West modern elements of tax system by improving and using new methods on the area of taxes and fees. Also were made the basics of recording and documenting of taxes, along with accounting expertize. Regulations on taxes started to be implemented in 2000 and this could be considered as foundation of tax system in Kosovo.

New tax system was drafted based on issuance of taxes on direct and indirect way.

- Direct tax (Personal Income Tax, Profit Tax, tax on small businesses and fees)

- Indirect taxes (VAT, excise and customs duties).

Immediately after the war, within the Ministry of Finance and economy, fiscal policy on collection of revenues for budget is based on administration levels on:

- Central level, with two main agencies, that are: central tax administration and customs administration; and

- Regional level, with the extent of regional offices of tax administration and customs administration.

The aim of policy is on presentation of a fiscal authority, which in order to overcome local and international challenges, believes that taxpayer compliance can be achieved voluntarily by them and with the increase of administration role, as close cooperator, can offer service excellence, e.g.

- To ensure clear instruction for taxpayers;

- To provide consolidated electronic services of interaction with taxpayers

- To better use the information technology platform that we have available;

- To make easier for taxpayers the compliance, and actively encourage those who use electronic channels to contact us;

- Regularly seek for feedback from taxpayers on needs and their expectations, and their satisfaction with TAK;

- To make challenging standards of performance and to act timely to fulfil them;

- Exchange information with other organizations to enable better services for citizens, as long as we respect their privacy;

- To follow up with news of other tax administration and private sector to seek for possibilities of improvements.

\section{Tax Base}

Tax base in Kosovo consists of three tax types:

- Value Added Tax

- $\quad$ Corporate Income Tax

- Personal Income Tax

These tax types have been changed towards simplification and provision of tax incentives by reducing and adopting tax rates with the level of regional countries. It is done the harmonization of legal provisions on Personal and Corporate Income Tax, and the harmonization of Vat law with European Union Directive on VAT. There have been drafted and approved sub-legal acts for tax laws implementation.

\begin{tabular}{|c|c|c|}
\hline \multicolumn{3}{|c|}{ Value Added Tax and tax rates in \% } \\
\hline Till 2008 & From 2009 -2015 & From 2015 \\
\hline $15 \%$ & $16 \%$ & $8 \%$ and $18 \%$ \\
\hline
\end{tabular}

Taxpayers who pay Value Added Tax until August 2015 are taxpayers with annual turnover over 50,000 euros, from September 2015 are the taxpayers with annual turnover over 30,000 euro and those who opt to register on voluntary basis.

\begin{tabular}{|c|c|}
\hline Corporate Income Tax and tax rates in \% \\
\hline Till 2008 & From 2009 \\
\hline $20 \%$ & $10 \%$ \\
\hline
\end{tabular}

\begin{tabular}{|c|c|c|c|}
\hline \multicolumn{2}{|c|}{ Personal Income Tax and tax rates in \% } & \multicolumn{2}{|c|}{ Tax rate in \% } \\
\hline \multicolumn{2}{|c|}{ Level of monthly income in $€$} & Till 2008 & From January 2009 \\
\hline Month & Annual & $0 \%$ & $0 \%$ \\
\hline Till $80 €$ & $960 €$ & $5 \%$ & $4 \%$ \\
\hline $80-250 €$ & $960 €-3000 €$ & $10 \%$ & $8 \%$ \\
\hline $250-450 €$ & $3.000 €-5.400 €$ & $20 \%$ & $10 \%$ \\
\hline Over $450 €$ & Over $5.400 €$ & \multicolumn{2}{c}{} \\
\hline
\end{tabular}


During its development the tax administration always supported by USAID and GIZ has established a culture we want revival of our values as Professionalism: Integrity and Honesty; Efficiency and Effectiveness; Transparency; providing electronic services as:

- EDI - Electronic Filing

- Search the taxpayer

- Download Tax Forms

- Report on purchases over 500 euro

- Application for fiscal receipts

- Tax Verification

- Calculate the wage

- Book of purchases and sales

Current tax system in Kosovo is designed to be simple both for business and for administration. Until 2009, Kosovo has applied a single tax rate $20 \%$ on profit tax, while the neighbor countries were having lower rates, which was creating an unfavorable climate for potential investors. Also, most of the countries in the region have higher VAT rates in relation to Kosovo, and within VAT they apply reduced rate for certain category of goods while Kosovo is applying only two tax rates $0 \%$ and $15 \%$. In general, all tax rates in Kosovo compare to some other countries we will understand that there is possibility of changes that should be proven and designed in line with government policies and objective based on facts arising as result of accompanying analysis.

\section{Corporate Income Tax}

With regulation No. 2004/51 from 1 January 2005 has started to be implemented with a rate of $20 \%$

This type of tax on corporate income is paid by taxable persons registered with status of legal person, and personal businesses or individual partners in partnership are not subject to Corporate Income Tax and instead they are subject to Personal Income Tax.

In December 2008, Corporate Income Tax regulates some legal provisions for nonresident persons, expenses, depreciation, etc., but most important is that for the period 2009 and on the tax rate is reduced to $10 \%$ of profit.

From period of 2005, there are also some changes on legal provisions on the change of rates on recognition of representation costs that are limited to one percent (1\%) on annual gross income. For more details related to this type of tax see the Law No. 05/L-029 on Corporate Income Tax.

\section{Value Added Tax}

Value Added Tax - VAT is tax on consumption (turnover of goods and services). It is calculated with applicable rates and is charged on different phases of production, distribution and life circle of trading of goods and services, and in the end is charged to consumer, so as such is indirect tax.

\section{Period 2001-2009}

The standard rate of Value Added Tax - VAT is 15\% of value of imported supplies and domestic taxable supplies with exclusion of those that are exempt and those that are treated as exports with $0 \%$ rate.

Business with turnover over 50,000 € within 12 months of calendar year (January - December) are obliged to register for VAT. Businesses with turnover under this amount may opt to register voluntarily for VAT.

\section{Period 2009-2015}

Value Added Tax (VAT) standard rate is $16 \%$ on the value of imported supplies and domestic taxable supplies with exclusion of those that are exempt and those that are treated as exports. Business with turnover over $50,000 €$ within 12 months of calendar year (January - December) are obliged to register for VAT. Businesses with turnover under this amount may opt to register voluntarily for VAT. Businesses with turnover under 50,000 € within last 12 months that are importing or exporting must register for VAT as Importers or Exporters, but are not required to file for VAT. It shout be emphasized that manufactures who import capital assets, the VAT payment can be differed for six months. In line with EU principles and VAT, exports are taxed with the rate of zero percent (0\%). VAT on imports is collected at the Kosovo 
state borders. The carrier of transaction pays the VAT on Customs basic value and on any importation other tax (customs duties and excise, if applicable) regardless of their origin. VAT is charged on imports and on any supply of goods and services with exclusion of those that by the law are considered as exempt supplies. Under the Law No. 03/L-146 on VAT, some supplies are exempt from VAT.

VAT exempt supplies are: - exports, - supply of goods and services in relation to international transportation, supply of goods or services under the diplomatic and consular arrangements, - supply of goods or services for international and intergovernmental bodies recognized as such by Kosovo public authorities, - supply of goods or services to NATO and KFOR, - supply of gold for Central Bank, - irrigation of agriculture land, - supply of goods and services financed by donation income (transitional period), - supply of goods and services made for United Nations or its agencies, World Bank and intergovernmental international organizations.

The period 9/2015 brought changes on Value Added Tax

This law itself brings reformulation of VAT existing law and cancelation of some existing provisions.

Change of tax rates:

$>$ Standard rate of VAT from $16 \%$ to $18 \%$.

$>$ Reduced rate of VAT 8\%,

Goods/services with the rate of $8 \%$ are:

- Water supply, but excluding packet water;

- Electric power supply, including distribution and transmission services, with central heating, refuse collection and treatment of other waste;

- Cereal grains such as barley, corn, maize, oats, rye, rise and wheat

- Products made from cereal grains intended for human consumption, such as flour, breakfast cereals, pastas, bread, and similar product;

- Cooking oils made from grains or oil seeds intended for use in cooking for human consumption;

- Milk and milk products intended for human consumption

- Salt, suitable for human consumption;

- Eggs for consumption;

- School books and serial publications;

Changes there have been made by existing law on refunds, as well:

- The VAT refund claim can be made if taxable person has carried forward VAT deductible excess for three months in the row (not three calendar months); and

- If VAT amount credit in the end of each quarter exceeds 3,000 euro (previously 5,000 €).

For more information on VAT see the Law 09/2015 on www.atk-ks.org.

\section{Conclusions}

Tax system is an important cell in economy of a country, because as we know the largest part of budget revenues is realized form tax collection.

Kosovo has gone through a difficult period with regard of tax system. Despite efforts for improvements of tax system, still, there a lot to be done to achieve a certain standard. To achieve this standard it is required a strong and stable tax administration because of informality we have in the economy, the tax evasion and corruption.

An efficient tax system shows a developing economy, where Kosovo is among countries with economic growth.

In order for a tax system to develop forever, every individual should have the voluntary spirit to comply with tax liabilities, for a certain aim that is the improvement of economic wealth of a country.

\section{References}

www.atk-ks.org

www.mef-ks.org 